$\begin{array}{ll}\text { Abstracta Iranica } & \begin{array}{l}\text { Abstracta Iranica } \\ \text { Revue bibliographique pour le domaine irano-aryen }\end{array} \\ & \text { Volume } \mathbf{2 9 |} \mathbf{2 0 0 8} \\ & \text { Comptes rendus des publications de } \mathbf{2 0 0 6}\end{array}$

\title{
The Places in Between. Harvest Books, 2006, 320 p.
}

\section{Anicée Van Engeland}

\section{OpenEdition}

Journals

Édition électronique

URL : http://journals.openedition.org/abstractairanica/33082

DOI : 10.4000/abstractairanica.33082

ISSN : 1961-960X

Éditeur :

CNRS (UMR 7528 Mondes iraniens et indiens), Éditions de l'IFRI

Édition imprimée

Date de publication : 15 mai 2008

ISSN : 0240-8910

\section{Référence électronique}

Anicée Van Engeland, «The Places in Between. Harvest Books, 2006, 320 p. », Abstracta Iranica [En ligne], Volume 29 | 2008, document 405, mis en ligne le 15 septembre 2008, consulté le 26 septembre 2020. URL : http://journals.openedition.org/abstractairanica/33082 ; DOI : https://doi.org/10.4000/ abstractairanica.33082

Ce document a été généré automatiquement le 26 septembre 2020

Tous droits réservés 


\section{The Places in Between. Harvest Books, 2006, $320 \mathrm{p}$.}

\section{Anicée Van Engeland}

L'A. a traversé l'Afghanistan à pieds peu après la chute des Talibans. Il ressort de ce voyage un ouvrage sur les Afghans, leur culture et leur histoire. Il fait ainsi découvrir au lecteur des lieux insolites, éloignés de la civilisation. On sent de la part de l'auteur une volonté de protéger cette culture tout en la faisant connaître. Cet ouvrage présente aussi le témoignage des habitants de ce pays, du taliban repenti aux étudiants.

\section{INDEX}

Thèmes : 13.2. Afghanistan

\section{AUTEURS}

\section{ANICÉE VAN ENGELAND}

European University Institute - Florence 